\title{
PAULINE PATERNITY IN 1 THESSALONIANS
}

\author{
Trevor J. Burke
}

\begin{abstract}
Summary
Two aspects of Paul's paternal relations, hierarchy/authority and affection, towards his Thessalonian 'offspring' are investigated against the first century Jewish and Graeco-Roman views of fatherhood. Paul's relationship with the Thessalonians was a hierarchical one, similar to that of the paterfamilias (head of the household) who assumed the responsibility for socialising his children into the community. As the founder-father of the community, Paul may have regarded the Thessalonian church as in some sense belonging to him. However, his superordinate position is tempered by a more gentle formulation in that he exercised paternal (as opposed to apostolic) authority towards his converts. Contrary to some views, there is an abundance of evidence in 1 Thessalonians to show that Paul was not averse to showing affection towards his converts. The apostle demonstrates his love in different ways, but it is his sudden physical separation from the Thessalonians - a severance that is akin to a 'death' or a 'bereavement'which calls forth an unprecedented display of tenderness. This also compares favourably with the response of ancient fathers when their offspring died. The article concludes that any proper view of Paul's paternity needs to account for the dialectic between his superordinate status and the deep love he also felt for his 'children'.
\end{abstract}

\section{Introduction}

Despite the fact that the apostle Paul argues quite forcibly in favour of celibacy, he makes a surprising number of references to fathers and children in his letters (1 Thes. 2:11-12; 1 Cor. 4:14-16; Phil. 2:22; Phlm. 10). ${ }^{1}$ None of the aforementioned address real fathers and their

1 In 1 Cor. 4:17 and Philemon 10 Paul also speaks of Timothy and Philemon, his co-workers, as his 'children' because they too had been converted through him. 
offspring; rather they are all metaphorical, serving the purpose of defining Paul's relationship between himself and his converts.

Traditionally, Paul's self-identification as 'father' has been viewed as a natural role for him to adopt, given the fact that he was the founding-father of a number of communities, including the ekklesia at Thessalonica. ${ }^{2}$ For example, Robert Banks depicts Paul's relationship to his spiritual offspring as one which is of a deep and personal nature and where he emphasises his pastoral care in the bringing of his converts to spiritual maturity. ${ }^{3}$ Similarly, Ernest Best devotes a full monograph to the subject of Paul's relationship with his communities, where the apostle's fatherly role is considered and seen to originate in his association with them at their conversion. Best's conclusion regarding Paul's paternal role is that it could suggest authoritarianism but 'need not be if its governing power is love'. ${ }^{4}$

This positive state of affairs vis-à-vis Paul's paternity, however, was to change quite dramatically, partly as a result of the emergence of new approaches among a number of feminist scholars. ${ }^{5}$ More

2 E. Best, 'Paul's Apostolic Authority-?' JSNT 27 (1986), 3-25, p. 17. He further states 'Though we may speak theologically of Christ as the founder of the church if we were to use sociological terms we would speak of Paul as founder of the churches at Corinth, Galatia, Philippi, etc.' See also B. Holmberg, Paul and Power: The Structure of Authority in the Primitive Churches as Reflected in the Pauline Epistles (Philadelphia: Fortress, 1991), pp. $79 \mathrm{ff}$.

3 Paul's Idea of Community: The Early House Churches in Their Historical Setting (Sydney: Anzea, 1979), p. 56.

4 Paul and His Converts (Edinburgh: T. \& T. Clark, 1986), p. 29. We agree with Best that Paul exercised authority over his churches (see later discussion) but note his false 'either/or' antithesis as far as Pauline authority and affection is concerned.

5 Elizabeth Schüssler Fiorenza's views are well known. For example, regarding Mk. 10:30 she puts much emphasis upon Jesus' response to his disciples: "The discipleship community abolishes the claims of the patriarchal family and constitutes a new familial community, one that does not include fathers in its circle' (In Memory of Her: A Feminist Theological Reconstruction of Christian Origins [New York: Crossroads, 1983], p. 147). Schüssler Fiorenza also makes much of the fact that in Mt. 23:8-10 Jesus states that no man on earth is to be called 'father' (p. 150). But this text also states that no one is to be called 'teacher' or 'master' and on this basis it is hardly justifiable to come to any conclusion vis-à-vis the organisation of early Christian communities. She also prefers to talk about an egalitarian model where the Christian movement corresponded to the associations of the so-called clubs, the collegia of Antiquity (e.g. pp. 180-81). But in our view she fails to appreciate fully that an egalitarian model is very different to social reality and the social reality of early Christianity was probably more patriarchal and household-like than nonpatriarchal. In passing it should be noted that the terms egalitarian and patriarchal are not, as is commonly thought, opposing viewpoints. The former 
specifically, Elisabeth Castelli, borrowing heavily from the findings of the post-structuralist and historian Michael Foucault, is of the opinion that Paul's claim to authority as the 'father' of his communities is not benign, but a wholly authoritative claim carrying the weight of the full juristic rights similar to that of a father in the Graeco-Roman world. ${ }^{6}$ Essentially Castelli views Paul's fatherhood as one aspect of Paul's hierarchical and authoritarian stance which is channeled through his call to 'mimesis' (imitation). Such authority is derived from his identification and authority with Christ, and his 'self-ascribed role' and special authority to speak as 'contentless conduit', an authority which stems from, and is based upon, the Lord whom he represents. However, concerning Paul's paternity, Castelli concludes, 'the paternal metaphor does not necessarily evoke a sense of kindness or love.'7

It is our opinion that this one-sided view to Paul's paternal role gives no room whatever for a proper appraisal of the apostle's fatherly affection towards his converts. The contention of this article is that any correct understanding of Paul's role as 'father' towards the Thessalonians needs to account adequately for his hierarchical position and authority and his affection for his converts, and that these two aspects are not mutually exclusive.

To help us test this hypothesis, this essay will be divided into two main parts. First, we shall examine these two aspects (hierarchy/authority and affection) of father-son relations in antiquity. ${ }^{8}$ Here we shall select a number of pertinent Jewish and Graeco-Roman texts. It is our view that the broad purpose of fatherson ${ }^{9}$ relations in the ancient world provides a useful comparative

belongs more to the semantic field of politics whilst the latter belongs to the semantic field of kinship. We need to compare like with like.

6 E. Castelli, Imitation of Paul: A Discourse of Power (Westminster/John Knox: Louisville/Kentucky, 1991).

7 Castelli, Imitation, 109. Also, as far as the imitation of Paul is concerned, Castelli states: 'mimesis Paulou is no simple case of emulating a benign ethical model' (p. 117) (emphasis added).

8 Paul's paternal role in 1 Thessalonians is profound and many-sided. I am currently investigating other aspects of this role, e.g. imitation, moral instruction, discipline, protection, etc. Also, an important and integral part of the parent-child relationship in antiquity is the principle of reciprocity.

9 A. Reinhartz ('Parents and Children in Philo', in The Jewish Family in Antiquity, ed. Shaye J.D. Cohen [BJS, 289; Atlanta: Scholars, 1993], pp. 61-88) states: "His [Philo's] remarks to "parents" and "children" are in reality addressed primarily to males in their roles as fathers and sons....The Philonic emphasis on the father-son relationship is consistent with Philo's general view on the superiority of male to female as well as being the likelihood that men constituted Philo's intended audience.' Similarly, as regards Roman families, E. 
context for studying Paul's paternal role in 1 Thessalonians. More important, it situates Paul in a historical context that should enable us to determine how the apostle may have employed this aspiration for the purposes of clarifying his own relationship between himself and his converts. This will be followed by an examination of 1 Thessalonians 2:11-12, once we have provided the necessary sociohistorical backdrop against which to interpret this passage more adequately.

\section{Paternal Relations in the Ancient World}

\section{Hierarchy/Authority}

(i) Jewish Evidence. Philo, more than any other author in antiquity, writes of the obligations of parents in the rearing of their offspring. ${ }^{10}$ Essentially the parent-child relationship is an hierarchical one and the fundamental bed-rock of the Jewish family. 11 This is clearly illustrated in the philosopher's comments on the fifth commandment: 'In the fifth commandment on honouring parents we have a suggestion of many necessary laws drawn up to deal with the relations of old and young, rulers to subjects, benefactors to

M. Lassen ('The Roman Family as Ideal and Metaphor', in Constructing Early Christian Families: Family as Social Reality and Metaphor, ed. H. Moxnes [London: Routledge, 1997], pp. 103-120) states: 'The Romans did not view themselves as a society of mothers, daughters, and brothers, but rather as a society of fathers and sons' (emphasis added).

$10 \mathrm{O}$. Larry Yarbrough, 'Parents and Children in the Jewish Family in Antiquity', in The Jewish Family, 39-60. Remarks about the parent-child relationship can be seen in every extant treatise of Philo's Exposition of the Law. Some might question the usefulness of Philo's writings vis-à-vis familial relations, given that his approach to scripture is essentially allegorical. However, it needs to be understood that even though Philo discusses the parent-child relationship within the confines of biblical law, there are occasions when he not only adds details but goes beyond the boundary of biblical exegesis. For example, in his thorough treatment of the fifth commandment he enjoins honour to be shown not only to parents but also to elders, the latter of which is not mentioned in either Ex. 20:12 or Dt. 5:16. Again, Philo vigorously condemns infanticide and the exposure of infants, two issues about which scripture is signally silent (cf. Ex. 21:22; Lv. 22:27). Therefore, Philo is not merely content to provide an exposition of scripture but his remarks on parents and children shed some light on his own thinking and 'the social and legal ramifications as he saw them'; see Reinhartz, 'Parents and Children' in The Jewish Family, 61-88.

11 According to W.H. Wagner ('Philo and Paideia', Cithara 10 [1971], 5374), 'Conceptually as well as cosmologically Philo's whole approach was hierarchical.' 
benefited, slaves to masters. For parents belong to the superior class of the above mentioned pairs, that which comprises seniors, rulers, benefactors and masters, while children occupy the lower position with juniors...' (Dec. 165-66; cf. Spec. Leg. 2.226-27).12 Such a hierarchical relationship, states Philo, is grounded in the creative activity which parents share with God: 'I say...that the maker is always senior to the thing made and the cause to its effect, and the begetters are in a sense the causes and the creators of what they beget' (Spec. Leg. 2.228). Elsewhere Philo states that the household is structured so that the 'father [is] the head of the house' (Mut. Nom. 217). Pseudo-Phocylides, in his didactic poem, makes a similarly hierarchical remark when he states that honour is to be shown 'first [to] God' and 'thereafter your parents' (Sent. 8). ${ }^{13}$ Josephus views all relationships as hierarchical-be they male or female - and turns to the Torah for corroboration: 'The woman, says the law, is in all things inferior to the man' (Ap. 2.199). For Josephus, the parent-child relationship is an integral part of this hierarchical framework since this is not only part of God's design but also his desire for society as a whole. In this arrangement parents are their children's elders and 'God is the most ancient of all' (Ap. 2.206).

Closely allied to the hierarchical nature of the parent-child relationship is the fact, as Philo declares, that 'parents have... received authority over their offspring' (Spec. Leg. 2.231). Likewise Josephus comments that 'authority has been given to man by God' (Ap. 2.201). Indeed, for Philo, as for the Romans, a father is regarded as the owner of all his children because they, like slaves, are born into their parents' household and require to be supported. ${ }^{14}$

12 All citations from ancient sources, unless otherwise stated, are from the Loeb Classical Library and utilise the Loeb references.

13 Translation by P.W. Van der Worst, The Sentences of Pseudo-Phocylides with Introduction and Commentary (Leiden: Brill, 1978).

14 The patriarchal focus of Philo's discussion has provoked a debate as to whether the author was drawing from Roman law regarding the patria potestas (i.e. the absolute power which a father had over his household). E.R. Goodenough (Jurisprudence of the Jewish Courts in Egypt [New Haven: Yale University Press, 1929], pp. 70-76) argues 'that the parent is described in Roman terms throughout' and that the father is the owner of his children; see also I. Heinemann who comments on Spec. Leg. 2.232, 'Philo verstärkt somit die Befügnis des Vaters sowohl der Frau wie den Kindern gegenüber, im Vergleich mit dem biblischen, geschweige dem rabbinischen Reicht; dem römischen Begriff der patria potestas, den er ja kannte und der auch auf das griechische Recht Einfluß gewann, mag er sich nahe gefühlt haben; auch die ägyptische Bestimmung die auf die Tötung erwachsener Kinder keine Todesstrafe setzte, könnte er gekannt haben' (Philons griechische und jüdische Bildung [Breslau: M. and H. Marcus, 1932], p. 250). 
In this respect, Philo uses the metaphor of the relationships of master and servants to describe the parents' authority over the their offspring, invoking a model of ownership and absolute dependence: 'Parents have not only been given the right of exercising authority over their children, but the power of a master corresponding to the two primary forms under which servants are owned' (Spec. Leg. 2.233).

(ii) Graeco-Roman Evidence. Unlike our Jewish authors already considered, the topos of 'household management' is one which is repeatedly addressed by Graeco-Roman writers. ${ }^{15}$ For instance, according to Aristotle, the household was a paradigm of the political order and comprises people of different rank in which some are more fit to rule (e.g. fathers) while others (e.g. children) are to serve (Pol. I.i.1-12). The superiority of the parents over the child is fundamental to Aristotle's understanding in the sense that authority and subordination undergirds the structure of the household in which the father rules over his children (Pol. I.v.1-2). Aristotle likens a child's relationship to his father to a relationship to one's god and employs regal language to express it: 'The rule of the father over the children...is that of a king; for the male parent is the ruler in virtue both of affection and of seniority, which is characteristic of royal government' (Pol. I.v.2). As such the father governs his children in a hierarchical relationship, but nonetheless one between free people (Eth. Nich. VIII.xi.2; cf. Pol. I.v.2). One of the primary responsibility of the male is the 'government of [his] children' and this, declares Aristotle, is one of the three components of 'household management' (Pol. I.ii.1; cf. I.v.2).

Similar views are articulated by Plutarch (c. 50-120 CE), the middle Platonist and rhetorician, who also puts parents on a hierarchical scale, regarding them as second in rank to that of the gods (Frat. Amor. 4/479F). As such — and here one can see how Plutarch's views of philosophy are essentially didactic in nature-it teaches children 'to reverence....[and] honour ones' parents...to be obedient... and yield to those in authority' (De Lib. 10). Similarly, Hierocles, the early second century Stoic, states that parents are due the highest honour and respect since they, 'most like the gods' are 'far superior'

15 This is partly due to the understanding philosophers had regarding the importance of the household as the basic building-block of society. Indeed, according to Aristotle, the oikia, the family, precedes and is more fundamental than the polis: the first community is the family (Pol. I.i.4; cf. Eth. Nich. VIII.xii.7). 
(4.25.53), ${ }^{16}$ while Seneca (c. 4 BCE-63 CE), the Roman statesman, in his treatise De Beneficiis informs us that children are to be obedient to their parents and to 'give way to their authority' (De Ben. III.xxxvii.1-3).

Like Philo, both Aristotle and Hierocles state that a child throughout his life is viewed as belonging to its parents. The former comments: 'that which springs from the thing belongs to the thing from which it springs' (Eth. Nich. VIII.xii.2). This aspect of ownership is made clearer in the following statement: 'Children are a good possessed by both parents in common, and common property holds people together' (Eth. Nich. VIII.xii.7). Hierocles, similarly, remarks that a child's existence is due to the fact that they belong to their parents: 'For whose possession should we rather be than those through whom we exist?' (4.25.53).

It is also instructive to note that whilst the relationship between parents and children is a hierarchical and authoritarian one, some evidence (both Jewish and Graeco-Roman) from two authors appears to soften this view. For instance, Pseudo-Phocylides sounds the caveat in matters of authority that parents ought not to be heavy handed towards their offspring; parents should 'not be harsh with [their] children, but gentle ( $\ddot{\pi} \mathrm{iol})$ ' (Sent. 208). Again, Plutarch in similar vein states that 'fathers...should not be utterly harsh and austere' (De Lib. 13/E).

\section{Affection}

If relations between fathers and their offspring in the ancient world were essentially hierarchical, this need not exclude the fact that the former were also capable of showing affection. ${ }^{17}$ Philo, in his

16 References to Hierocles are found in A.J. Malherbe, Moral Exhortation: A Graeco-Roman Sourcebook (LEC 4; Philadelphia: Westminster, 1987).

17 R. Saller ('Corporal Punishment, Authority and Obedience in the Roman Household', in Marriage, Children and Divorce in Ancient Rome, ed. B. Rawson [Oxford: Clarendon, 1991], 144-65) makes the point that 'If the father had been [a] severe repressive figure in Roman culture...it would have been odd that emperors were so concerned to represent themselves as pater in contrast to dominus... The rationale for this image was surely precisely the fact that fathers exercised a benign authority' (p. 165, n. 33) (emphasis added). Moreover, the emperor's title was pater patriae ('father of the Fatherland'). In this respect Castelli's legalistically driven analysis completely neglects the affective aspect of paternal responsibility. This is partly due to her overly selective choice of primary sources. For example, she is critical of scholars who try, in her view unsuccessfully, to use some of Epictetus' writings (e.g. Diss. 3.22.95ff.) to argue a case for paternal love. However, Castelli fails to consider other passages in the same discourse where affection is clearly manifested (e.g. Diss. 1.11.4, 5-6; 1.23.5; 2.22.4). Increasingly classical scholars are of the 
explication of the legal texts, provides evidence of the fact that he regards the father-son relationship as an affective one. ${ }^{18}$ In the first book of his De Specialibus Legibus Philo states that 'children are...inseparable parts [of their parents], joined to them by kinship of blood,...by the love-ties of the affection that unites them...' (Spec. Leg. 1.137).

Something of the all-absorbing passion and sacrifice parents made on behalf of their offspring is evident in the following remark: 'parents have little of their own personal interests and find the consummation of happiness in the high excellence of their children' (Spec. Leg. 2.236). To be sure, Philo knows of the danger of overindulgence of one's children. Nevertheless, even in this context there is no mistaking the love, 'the exceeding tenderheartedness' ( $\tau$ ò $\lambda i \alpha v \phi i \lambda$ ó $\tau \tau o \rho \gamma o v)$, which is expressed: 'parents cherish their

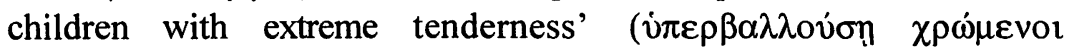

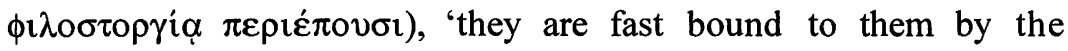

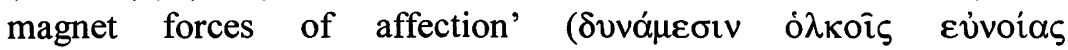

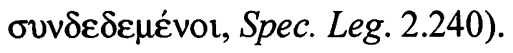

Even Philo's allegorical works provide evidence of paternal affection. In his treatise De Josepho he tells us that whilst all offspring are the recipients of their father's love, a father's love for a child born in his latter years is worthy of special affection: '[Jacob's] love for this child of his later years...exceeded his love for his other sons' (Jos. 4). ${ }^{19}$ Likewise in his exposition of the Abraham narrative Isaac is spoken of as the patriarch's 'only darling son'

opinion that the affective side of father-son relations in antiquity has been overlooked. A new view is emerging. E. Eyben ('Fathers and Sons', in Marriage, Children and Divorce, pp. 114-43) states that: 'Paternal love, was... a reality in Antiquity' (p. 119); see also S. Dixon ('The Sentimental Ideal of the Roman Family', in Marriage, Children and Divorce, pp. 99-113) for the view that the sentimental ideal possibly originated and flourished in the late Republic. Also M. Manson in an influential article ('The Emergence of the Small Child in Rome [Third Century BC-First Century AD]', History of Education 12 [1983], pp. 143-59) argues that the child became more personalised and terms of affection and affectionate gestures became more prominent; see also M. Golden, 'Did the Ancients Care When Their Children Died?' Greece \& Rome 35 (1988), 152-63.

18 Reinhartz states that even within the course 'of such exposition [i.e. within the context of biblical laws], it is clear that love and affection, particularly of parents towards children, was considered by Philo to be not only a desideratum but in most cases a very powerful aspect of parenthood' ('Parents and Children', p. 81).

19 Philo provides many details in this narrative, which go beyond the boundary of biblical exegesis. See M. Niehoff, The Figure of Joseph in Post-Biblical Jewish Literature (Brill: Leiden, 1992), p. 60. 


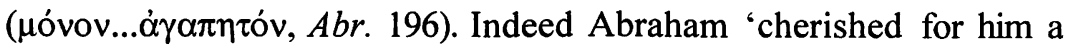

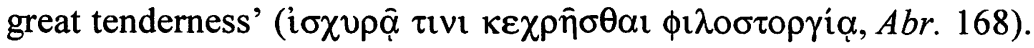

Josephus, like Philo, not only comments upon the biblical narratives but is prepared, at times, to go beyond them thereby giving some insights of his own. ${ }^{20}$ In his Antiquities the historian relates Abraham's readiness to sacrifice his son Isaac a son who was 'passionately beloved of his father' (i $\pi \varepsilon \rho \alpha \gamma \alpha \pi \alpha \dot{\alpha} \omega) .{ }^{21}$ Again, in the story of Joseph, also heightened by the writer, we read of the emotional struggle when Jacob and Joseph were finally reunited: 'Joseph went out to meet him...Jacob from joy, so unlooked for and so great was like to die, but Joseph revived him; he too was not master enough of himself to resist the same emotions of delight but was not, like his father, overcome by it' (Ant. 2.184).

When we turn to the Graeco-Roman literature, affection is also a defining characteristic of the parent-child relationship. Aristotle discusses love within the context of friendship and notes that the affection between a parent and a child is a mutual but, nonetheless, hierarchical emotion. Children love their parents too, but not as much as their parents love them. Whereas Philo's discussions of family affection reveal a degree of mutuality of this aspect of the parentchild relationship, Aristotle states that parents' love for their offspring is both greater and longer: 'For parents love their children as part of themselves, whereas children love their parents as the source of their being...progenitor is more attached to progeny than progeny to progenitor...parents love their children as soon as they are born, children their parents only when time has elapsed and they have acquired understanding' (Eth. Nich. VIII.xii.2).

Plutarch, is one writer among many, who reminds us how procreation was the expected outcome of all marriages; nevertheless, he goes on to state that parents have in view an even higher goal than this: 'the aim of bearing and rearing of a child is not utility, but affection ( $\phi i \lambda i \alpha v)$ ' (De Amor. 3/496C). The same writer also informs

20 L.H. Feldmann ('Flavius Josephus; The Man, His Writings, and His Significance', $A N R W$ II 21.2 [1984], 797) writes that this helps to 'heighten the pathos of the narrative'. On a more general note, J.M.G. Barclay (Jews in the Mediterranean Diaspora: From Alexander to Trajan $\{323 B C-117 C E\}$ [Edinburgh: T. \& T. Clark, 1996], p. 357) writes: 'Biblical figures are given characterisation....and a premium is placed on emotion, pathos and suspense' (emphasis added).

21 Elsewhere Josephus explicitly informs us that Jacob's love for Joseph was one of the reasons which caused the latter such trouble: 'The affection $(\sigma \tau \rho \rho \gamma \eta \dot{ })$ of his father, aroused against him the envy and hatred of his brothers...' (Ant. 2.10). 
us that a father is even prepared to place affection for his children above personal achievement and honour: 'No father is fond of oratory or of honour or of riches as he is of his children' (De Amor. $5 / 480$ C). Seneca echoes similar sentiments in his treatise $D e$ Providentia in which he grapples with the question of why God, as a loving father, may sometimes allow evil to invade the lives of his 'cherished children'; it is because he wants strength to be developed out of adversity. So it is for human parents, but the manners in which a mother and father go about demonstrating their affection are quite different, as Seneca describes: 'Do you not see how fathers show their love in one way, and mothers in another? The father orders his children to be aroused from their sleep in order that they may start early upon their pursuits, even on holidays he does not permit them to be idle, and he draws from them sweat and sometimes tears.' On the other hand he concludes, 'the mother fondles them in her lap, wishes them out of the sun, wishes them not to be unhappy, never to cry, never to toil' (De Pr. 2.5).

Arguably two instances in the ancient world that evoked some of the most affective responses from fathers towards their children were bereavement and sickness (e.g. Epictetus, Diss. 1.11.4). As regards the former, antiquity is replete with examples of grieving and affectionate fathers. The well-known example of the death of Plutarch's two-year old child Tixomena is perhaps one of the most moving: 'You know yourself, you have reared so many children in partnership with me, all of them brought up at home under our care...Our affection for children so young has...a poignancy all of its own: the delight it gives is quite pure and free from all reproach...it is yielding to a parent's love to long for and honour and remember the departed' (Consol. 608D-609D). Epictetus also provides us with details of the attachment of affection of parents towards their children and the deep grief experienced when one of them dies (Diss. 3.24.84-94; 4.1.87, 99-101).

Pliny in his letters $(E p .3 .10,16 ; 4.2,7)$ recounts the effect that the premature death of his son had upon him. And Quintilian graphically describes his feelings upon the death of his two sons as 'the worst of tortures' (Inst. 6 Praef. 6), 'my agony' (6 Praef. 8), and 'my own sorrow...my own sad heart'(6 Praef. 10).

Given the fact that parent-child relations in antiquity were both hierarchical and affective, how do these compare with Paul's own relationship as pastor to his convert-children at Thessalonica? How does Paul relate to the Thessalonians? Are there any parallels or 
contrasts to be drawn? We turn now to an examination of Paul's relations to the Thessalonians (1 Thes. 2:11-12).

\section{Paul as 'Father' to His Thessalonian 'Children'}

In 1 Thessalonians 2:1-12 Paul is arguing on two fronts: first he is providing a defense 22 in light of the criticism leveled against him by unbelievers $^{23}$ and secondly, he posits a proper model for pastoral practice. In all this, the apostle is concerned to distance himself from those silver-tongued charlatans who pedal their teachings whilst charging exorbitant amounts to do so. This is evident by the number of denials he makes which serve to reinforce that Paul is counteracting personal accusations. Immediately prior to vv. 11-12 Paul appeals to the Thessalonians and again to God as his witness (v. 10) concerning his (and his colleagues') behaviour whilst he was with them. Grammatically, v. 11 is without a main verb making it dependent upon the main clause of v. 10 'you were witnesses,' as the parallel $\dot{\omega} \varsigma$ clauses of vv. 10 and 11 suggest. Various attempts at supplying an appropriate verb have been suggested such as, 'treated',24 or 'counselled',25 but since Paul is here likening himself 26

22 Paul appeals to God as witness in $2: 4 \mathrm{~b}$ as the one 'who tests our hearts'. He employs the disclosure formula ois $\delta \tau \varepsilon$ ('you [pl.] know') four times in this pericope. For example, he reminds the Thessalonians how he spoke the gospel

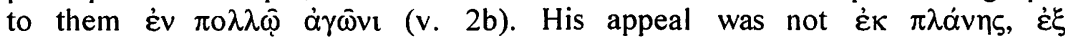

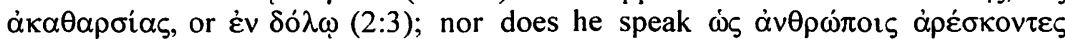
(2:4). For the view that Paul is here presenting a personal defence see J.M.G. Barclay, 'Conflict in Thessalonica', $C B Q 55$ (1993), 512-30, esp. p. 513 n. 4; J.A.D. Weima, 'An Apology for the Apologetic Function of 1 Thess. 2:1-12', JSNT 68 (1997), 73-99.

23 A smear campaign-which probably included slander-had been launched against Paul because of his hasty departure after establishing the Thessalonican community. His abrupt and forced exit was probably perceived by outsiders as indifference at having left a fledgling church on the lurch (I.H. Marshall, $l$ and 2 Thessalonians [NCBC; London: Marshall, Morgan and Scott, 1983], p. 5). F.F. Bruce's comment adroitly sums up the attitude and criticisms of these outsiders: 'A fine lot these Jewish spellbinders are! They come here and persuade you to join their following, but as soon as trouble blows up, off they go and leave their dupes to face the music' ( 1 and 2 Thessalonians [WBC 45; Word: Waco, Texas, 1982], xxv). Barclay has rightly emphasised the need, in any reconstruction of the setting of this letter, to account for 'the conflict in Thessalonica between Christians and non-Christians' ('Conflict in Thessalonica', p. 512).

24 Bruce, Thessalonians, p. 34.

25 E. Best, The First and Second Epistles to the Thessalonians (BNTC; London: Black, 1986), p. 106.

26 The use of the first person plural 'we' could be problematic for the 
to a father to his offspring, 'raised them up' 27 is probably better in this context. Paul was not only a father to the Thessalonican believers, but a 'founding-father' of the church and therefore felt responsible for the rearing of his spiritual 'children'.

The fact that Paul should cast himself more in the role of a 'father' than a 'mother' is not surprising given that he lived in a patriarchal society. ${ }^{28}$ Moreover, it is this patriarchal role which undergirds everything Paul is, and does, as a father for his Thessalonian converts. This is because the paterfamilias (head of the household) was essentially responsible for the entire socialisation of his children as they were incorporated into the family and wider community (secondary socialisation). In short, the patriarchal father was responsible for taking the leading role in the fundamental socialisation of his offspring into the socio-economic and cultural way of life into which they were born and subsequently raised. ${ }^{29}$

In 1 Thessalonians 2:11f. Paul acknowledges that he played just such a role with regard to the Thessalonians' new beliefs, their new way of life and the new social world of Christian existence to which they had been converted (cf. 1:9-10). ${ }^{30}$ To be sure, conversion is a

metaphor/simile because it implies that all three missionaries (i.e. Paul, Timothy and Silvanus) acted as fathers, something Paul does not state anywhere else in his letters. In Phil. 2:22 Paul informs us that Timothy served with him in the gospel 'like a child with his own father' and, on this evidence, Timothy is Paul's child in the faith, not a fellow 'father'. In light of this we should understand those occasions in 1 Thes. where the apostle uses the plural, the royal 'we', as Paul referring to himself without ever suggesting that these co-worker 'children' are his equals. A more problematic issue is how we are to understand 3:2-5 where the apostle states in v. 2 'we sent Timothy' only to declare a few verses later that 'he' (v. 5) had sent them. Perhaps this illustrates the difference between social reality and rhetoric which may go some way towards explaining the singular social reality behind the rhetorical plural in 1 Thes. 2:1-12.

27 C.A. Wanamaker, The Epistles to the Thessalonians: A Commentary on the Greek Text (NIGTC; Michigan/Exeter: Eerdmans/Paternoster, 1990), p. 106.

28 See the articles by B.R. Gaventa, 'The Maternity of Paul: An Exegetical Study of Galatians 4:19', in The Conversation Continues: Studies in Paul in Honour of J. Louis Martyn, eds. R. Fortuna and B.R. Gaventa (Abingdon Press: Nashville, 1990), pp. 189-200; idem, 'Our Mother St. Paul: Toward the Recovery of a Neglected Theme', Princeton Seminary Bulletin 17 (1996), 2944.

29 Wanamaker, Thessalonians, p. 15. I am indebted to Wanamaker for some of the insights that follow.

30 C.A. Wanamaker, "Like a Father Treats His Own Children": Paul and the Conversion of the Thessalonians', JTSA 92 (1995), 46-55; E.J. Richard, First and Second Thessalonians (Sacra Pagina 11; Collegeville, MN: Liturgical Press, 1995), p. 106. For a treatment of Paul's Role as paterfamilias to the 
theological matter and Paul informs us that the Thessalonians' conversion was 'a turning to God' (1:9); indeed in 5:1-12 the apostle states that his readers had been called into the kingdom of God, a new social world where God's will and rule were in operation, the implication being that the Thessalonians had been called out of their previous social world where God's authority was not acknowledged or accepted.

But conversion also involves becoming part of a new community and, in this regard, it is also important to note that by turning to God these early Christians were also 'welcoming Paul and his coworkers'. ${ }^{31}$ Moreover, in the Acts of the Apostles the conversion of the Thessalonians is described as a 'joining of Paul and Silas' (17:4; cf. v. 34). According to Berger and Luckmann, this is nothing less than a process of re-socialisation where the new converts leave behind old ties etc. and embrace new ones, and where Paul and his associates function as 'significant others';32 by doing this they drew their respective converts into a Christian world of experience with its own knowledge, role values, attitudes and social meaning. ${ }^{33}$ These 'significant others are the guides into the new reality' 34 who represent the 'plausibility structure' to the new convert and with whom the disciple must establish a strong affective identification. More important, since it is with Paul's role with which we concerned here, this process of re-socialisation will be all the more 'successful'

Corinthian community see S.J. Joubert, 'Managing the Household: Paul's Role as paterfamilias of the Christian Household Group in Corinth', in Modelling Early Christianity: Social-Scientific Studies of the New Testament in Its Context, ed. P.F. Esler (London and New York: Routledge, 1995), pp. 213-23.

31 K.O. Sandnes, A New Family: Conversion and Ecclesiology in the Early Church with Cross-Cultural Comparisons (Studies in the Intercultural History of Christianity 91; Bern: Peter Lang, 1994), p. 14. Sandnes presents the case for viewing the ekklesia as an 'alternative family' for the new convert. He rightly shows just how frequently the authors of the New Testament used familial metaphors, but surprisingly devotes more attention to Paul's letter to Philemon than to 1 Thessalonians. Apart from referring to 1 Thessalonians at the beginning of his work, Sandnes overlooks this letter as a most fruitful source of fictive kinship terms.

32 P.L. Berger and T. Luckmann, The Social Construction of Reality (London: Penguin, 1966), p. 177.

33 The need for 'significant others', acceptance, etc. becomes even more crucial in situations where conversion leads to familial and social dislocation/conflict and such was the case at Thessalonica; see Barclay, 'Conflict', 514-15.

34 Berger and Luckmann, Social Construction, p. 177. 
if the new community, i.e. the ekklesia that they join, resembles that of a family in which their primary socialisation took place. ${ }^{35}$

\section{Hierarchy/A uthority}

Paul could have related to his converts in one of a number of ways. In the first instance, he might have chosen a role which set him on the same level as the Thessalonians, ${ }^{36}$ or one which made him inferior ${ }^{37}$ or another which put him on a superior plane. As noted above, it is not surprising, given the fact that Paul lived in a patriarchal society, that he should adopt the superior-inferior role towards his spiritual offspring. It is significant to note that Paul never resorts to employing the sibling metaphor when describing his relationship to his converts (here or anywhere else in his letters for that matter). ${ }^{38}$ On most occasions Paul prefers to use the paternal

35 Berger and Luckmann, Social Construction, pp. 176ff. See A.J. Malherbe's article 'God's New Family in Thessalonica,' in The Social World of the First Christians: Essays in Honour of W.A. Meeks, eds. L. Michael White and O. Larry Yarbrough (Minneapolis: Fortress, 1995), pp. 116-25. For a discussion of how Berger and Luckmann's theory of re-socialisation can apply to another important familial term, viz. 'adoption', see the article by the present author: 'Pauline Adoption: A Sociological Approach,' EvQ (forthcoming).

36 Paul's favourite appellation for the Thessalonian Christians is the term 'brother'-he employs it no fewer than 19 times during the course of the letter. S.S. Bartchy ('Undermining Ancient Patriarchy: The Apostle Paul's Vision of a Society of Siblings', BTB 29 [1999], 68-78) thinks that Paul's 'primary relationship-framework for all followers of Jesus had become 'sisters and brothers', reflecting...the strong influence on Paul of the radical social codes and anti-patriarchal traditions associated with Jesus' (p. 69). Surprisingly, Bartchy fails to discuss 1 Thessalonians in his essay. Indeed Bartchy's understanding of brotherly relations may not be as non-patriarchal or as straightforward as he suggests. Bartchy fails to appreciate as Sandnes ( $A \mathrm{New}$ Family, p. 70) rightly points out that 'brothers, and elder brothers in particular, were also part of the patriarchal society'. Moreover, primary evidence can be adduced to show that hierarchical relations existed between brothers in the ancient world (e.g. Plutarch, Frat. Amor. 484D, 485C, 487C).

37 N.R. Peterson, Rediscovering Paul: Philemon and the Sociology of Paul's Narrative Thought World (Philadelphia: Fortress, 1985), p. 130. Paul even appears to invert this relationship with the Thessalonians when he refers to himself as having been 'orphaned' from them (cf. 2:17).

38 R. Aasgard, 'My Beloved Brothers and Sisters': A Study of the Meaning and Function of Christian Siblingship in Paul in Its Graeco-Roman and Jewish Context' (D.Th.; Oslo, 1998), p. 327. Bartchy ('Undermining', p. 69) also states: 'When Paul refers to himself as 'father', as he rarely does, it is almost always as a nurturing parent, not as a ruling patriarch.' But this is to confuse these two roles because when Paul wants to emphasis the nurturing side of his parental responsibility he employs a maternal (cf. 1 Thes. 2:7, 'nursingmother') metaphor. On the other hand, Paul uses the paternal metaphor to stress his educating role (cf. 1 Thes. 2:12), a function that corresponds with the obligation of the father in the ancient world. 
metaphor. By describing himself as a 'father' (2:11) Paul is employing 'a metaphor of unambiguous superiority'. 39 The parent-child metaphoric-complex expresses a hierarchical social-structural relationship well documented in our Jewish and Graeco-Roman sources in antiquity (e.g. Philo, Spec. Leg. 2.226-27; Aristotle, Pol. I.v.1-2). Since this role was taken for granted within Paul's own social world, it is not surprising to find that the apostle not only applied it to himself and the Thessalonians, but to all the churches that he established. ${ }^{40}$ Such a hierarchical relationship also means that Paul can make demands of his converts but can, at times, choose not to (1 Thes. 2:6) and that he expects them to respond like obedient children to their father when he taught and exhorted them concerning their Christian faith and manner of life (2:12).

It is a small step from thinking about Paul's hierarchical relationship to the authority of the patriarchal father in the ancient world. As we have already noted, the Thessalonians had come under God's authority but to do so was to come under Paul's 'delegated authority' (cf. 4:1), since he and his co-workers were entrusted with instructing the Thessalonians on how to please God (4:1). ${ }^{41}$ Such instructions, Paul acknowledges, were not his own but were given 'by the authority of the Lord Jesus' (4:2). Once Paul's converts had accepted the gospel that he and his co-workers articulated, it was only natural for their 'father-in-the-faith' to begin exerting his authority in the whole process of re-socialising them into the distinctively Christian way of life. 42 Indeed the twin aspects of hierarchy and authority were characteristics of the father-figure of the household in antiquity (cf. Aristotle, Pol. I.v.1-2; Eth. Nich. VIII.xi.2; Philo, Mut. Nom. 217; Spec. Leg. 2.233 all cited earlier). We have also observed how in the Graeco-Roman world the patriarch i.e. the paterfamilias was regarded (quite literally) as the owner of his children (cf. Philo, Spec. Leg. 2.233; Aristotle, Eth. Nich. VIII.xii.2, 7; Hierocles, 4.25 .53 all cited earlier). Since it is our thesis that the parent-child relationship provides a useful and comparative context for illuminating Paul's paternal role with the Thessalonians, it is not unreasonable to suggest that as the founding-father of the

39 Peterson, Rediscovering Paul, p. 130.

40 Peterson, Rediscovering Paul, p. 130.

41 R.F. Collins, Studies on the First Letter to the Thessalonians (BETL LXVI; Leuven: Leuven University Press, 1984), p. 360.

42 Best, Paul and His Converts, p. 81. 
Thessalonican community the apostle exercised in some sense 'ownership' of it. ${ }^{43}$

Given that we are discussing the question of Pauline authority, one other issue needs to be addressed. It has often been assumed that Paul based his authority upon his call to be an apostle, hence when Paul uses his authority he does so solely on the basis of his status.

To be sure, Paul was an apostle who exercised authority but does he exercise apostolic authority over his churches, including the ones he himself established? In other words, is Paul in the habit of employing his status to make demands of his own converts? That Paul exercised authority over the churches he founded is not doubted and is evident by the fact that he wrote letters to them and dispatched his assistants to instruct and advise them (3:2). In this regard it has been shown that even in those churches which he had established and where his apostleship was under doubt (Gal. 2:8; 1 Cor. 9:1; 2 Cor. 8:23), Paul never issues instructions based upon his apostolic status. ${ }^{44}$ Instead it is these very letters in which he employs his paternal role when exercising his authority (cf. 1 Cor. $3: 1-3 \mathrm{a} ; 4: 17 ; 2$ Cor. $6: 13 ; 12: 14) .{ }^{45}$

43 S.H. Polaski states: 'The churches Paul has founded belong to him' (Paul and the Discourse of Power [Sheffield: Sheffield Academic Press, 1999], p. 31). 44 Best, 'Authority', 15-18.

45 It is sometimes suggested that Paul's paternal role functions as a cover for his apostolic role (cf. Peterson, Rediscovering Paul, p. 131) which he used to remove the hierarchical relationships that existed between himself and his converts. But we ought not to confuse these two roles; they are quite distinct. As regards the latter, this is seen in the way he acts as 'broker of the heavenly patrons' (cf. Joubert, 'Managing the Household', pp. 216-22). This is depicted in 1 Thessalonians in the way Paul claims he was appointed as an 'apostle of Christ' (2:6) who was given instructions on the 'authority of the Lord Jesus' $(4: 2)$. Thus, compared to other leadership roles within the ekklesia, Paul's was originated from outside the community. Within the context of the letter, Paul recognises that his utterances were not merely the words of men but were, instead, 'words of power' (1:5) and 'words of God' (2:13) all of which were under the guidance of the Holy Spirit (1:5). On these grounds, Paul could therefore claim the highest rank for himself within the church; he was subservient to no one else. As far as Paul's paternal role is concerned, this is different in that it related to his status within the household under his care and was in keeping with his role as paterfamilias-Paul claimed the superordinate position for himself. So, although the terms 'apostle' and 'father' are not synonyms, they both have superordinate implications. Of course Paul uses the term 'apostle' in his letter to the Romans, but the absence of paternal imagery is not surprising since he had not founded that community. Paul expresses his apostolic credentials (Rom. 1:1) probably to alleviate the suspicions about him in other areas and which may have reached Rome. 
Significantly, the twin issues of apostleship and authority occur

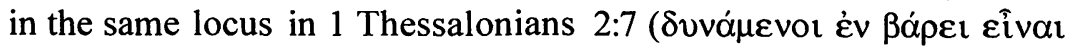

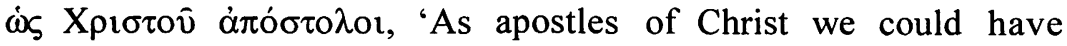
exercised our authority'). ${ }^{46}$ Unlike the situations at Galatia and Corinth, there is nothing in 1 Thessalonians to suggest that Paul's apostleship is being doubted. But it is instructive to note that although the apostle states he has every right to exercise his particular apostolic authority, he chooses not to. The participial phrase, 'We could have wielded our authority as apostles of Christ', is immediately followed by the strong adversative $\dot{\alpha} \lambda \lambda \dot{\alpha}$ (v. 7b) where, in the first instance, Paul draws a contrast between his right to employ such authority and his preference to be gentle ( $\tilde{\eta}^{2} \mathrm{Lr}^{47}$ ), which whilst immediately relating to his role as a 'nursing-mother', is also indicative of the kindness of a father. ${ }^{48}$ This anticipates what Paul is about to say in verse 11 where he elaborates more fully on his paternal role. Thus, here again it will be noticed that Paul's authority especially among his own converts is not as legalistic as may be

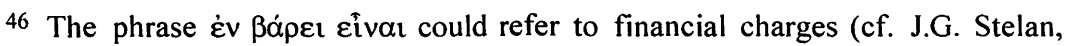
'Burden-Bearing and the Law of Christ: A Re-examination of Galatians 6:2', $J B L 94$ [1975], 266-76) however the word ßópos can also denote dignity, influence and authority and it is better to understand it in this way here (Wanamaker, Thessalonians, p. 99). Monetary matters and how Paul financed himself appears as a separate and new issue in verse 9 .

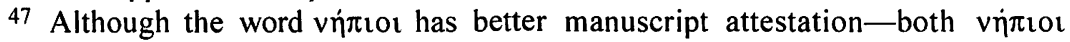
and $\eta \pi$ io could have resulted from scribal errors as a result of dittography or haplography respectivelypersuade us in this direction. First, ví $\pi$ เo involves too sharp a change of metaphor within one verse-even though Paul is known to do this elsewhere (2 Cor. 3:13-16; Rom. 7:1). To do so here would mean that the apostle first describes himself and his associates as 'babes' and then 'nurses' (nursingmothers) taking care of babes. Secondly, apart from Eph. 4:14, Paul nowhere likens himself to a vinitor; when he does employ this noun he does so of others and in a pejorative manner (cf. Gal. 4:1, 3; 1 Cor. 13:11; Rom. 2:20). C. Crawford ("The Tiny Problem of 1 Thess. 2:7: The Case of the Curious Vocative', Bib 54 [1973], 69-72) tries, in our view unsuccessfully, to get around the problem by retaining ví $\pi$ to but to take it as a vocative addressed to the Thessalonian believers; see the other literature which has grown up around this variant, F.J.J. van Rensburg, 'An Argument for Reading vin $\pi$ ior in 1 Thessalonians 2:7', in A South African Perspective on the New Testament: Essays by South African New Testament Scholars Presented to Bruce $M$. Metzger, eds. J. Petzer and Patrick J. Hartin (Leiden: Brill, 1986), pp. 252-59; B.R. Gaventa, 'Apostles as Babes and Nurses in 1 Thessalonians 2:7', in Faith and History: Essays in Honour of Paul W. Meyer, eds. J.T. Carroll, C.H. Cosgrove and E.E. Johnson (Atlanta: Scholars, 1990), pp. 193-207; S. Fowl, 'A Metaphor in Distress: A Reading of NHחIOI in 1 Thessalonians 2:7', NTS 36 (1990), 469-73; J. Delobel, 'One Letter Too Many in Paul's First Letter?: A Study of (v)ñ $\pi \mathrm{lot}$ in 1 Thess. 2:7', Louvain Studies 20 (1995), 126-33.

48 A.L. Moore, 1 and 2 Thessalonians (NCB; Camden: Nelson, 1969), p. 38. 
thought but is softened by his use of the paternal metaphor. In this respect, there is corroboration of this kind of approach in two of our ancient sources. Plutarch, whilst recognising that a parent possesses authority, sounds the caveat that 'fathers...should not be utterly harsh and austere' (De Lib. 13/E). And Pseudo-Phocylides' linguistically related (Sent. 207; cf. 1 Thes. 2:7) comment is more pertinent when he also instructs parents that they should 'not [be]

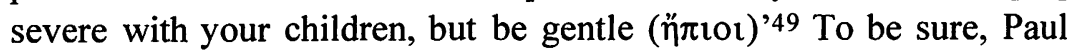
can give commands and orders when it is necessary but as far as authority and his own converts is concerned, this is mollified by his preference to exercise it in a paternal manner as opposed to using his apostolic credentials and the giving of strict commands. 50

\section{Affection}

If, as mentioned already, Paul's patriarchal role undergirds everything he is and does for the Thessalonians, his care and affection need also to be viewed against the wider backdrop of this

49 In light of the fact that $\eta \pi$ tor 'gentle' (in Paul) is the more likely reading, P.W. Van der Horst ('Pseudo-Phocylides and the New Testament', ZNW 69 [1978], 197) has suggested a literary relationship between Pseudo-Phocylides, Philo and Josephus to the extent 'that writings like those of these three authors were, in turn, sources for some New Testament authors' (emphasis added). If so, could Pseudo-Phocylides' text have been one possible influence (also cf. A.J. Malherbe, 'Gentle as a Nurse: The Cynic Background to 1 Thess. ii', NovT 12 [1970], 203-217) on Paul's use of the above Greek term 1 Thessalonians 2:7?

50 It is for this reason that we are unable to agree with E.M. Lassen's remark, namely, that Paul uses the 'father-concept...metaphorically...to assert his apostolic authority' ('The Use of the Father Image in Imperial Propaganda and 1 Corinthians', TynB 42 [1991], 127-36). In light of the overemphasis on depicting ancient societies as authoritarian and hierarchical, Lassen has rightly emphasised the caring and protective elements associated with paternal power. These aspects are reflected in the fact that successive emperors, from Caesar onwards, assumed the title Pater Patriae ('Father of the Fatherland'). However, Lassen in our view does not go far enough in that she does not take cognizance of the significance or the benign associations of this title (see n. 18). She also goes on to state that Paul would not have been unaware of this 'powerful Roman usage' and invokes it in his dealings with the Corinthian congregation (1 Cor. 4:14-21). In her view, the Corinthian Christians have a choice: they can either face Paul's chastisement (i.e. 'the rod', v. 21b) or welcome him ('in love', v. 21c). But this 'either/or' antithesis ought not to be overplayed as G.D. Fee (The First Epistle to the Corinthians [NICNT; Grand Rapids: Eerdmans, 1987], p. 193) rightly points out: 'his [Paul's] contrasts relate to the manner of his coming, not the motive, which would express love in either case'. Thus, whatever action Paul takes on this occasion, both clearly demonstrate his affection. For a description of love as a characteristic of Paul's fatherly care see A.A. Myrick, "Father" Imagery in 2 Corinthians 1-9 and Jewish Paternal Tradition', TynB 47 (1996), 163-71, esp. 168-70. 
letter. The mere fact that Paul wrote letters to his churches is evidence in itself of the apostle's concern and love for them. The

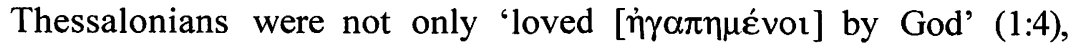
they also became Paul's own beloved. Indeed, so sacrificial was the apostle's love on behalf of the Thessalonians that he tells them 'we

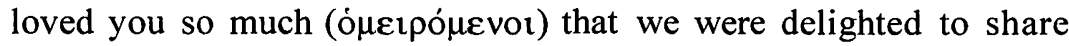
with you not only our gospel but our very lives as well, because you became so dear ( $\dot{\alpha} \gamma \alpha \pi \eta \tau o i)$ to us' (2:8). The apostle's affection for his converts is further demonstrated in what is generally regarded as one of the most emotive pericopes in the Pauline corpus (2:17$3: 11) .{ }^{51}$ Here, Paul, in highly charged terms, writes of his 'intense longing' (2:17) to see his offspring, from whom he has suddenly been separated. Indeed, such is the abortive nature of the severance that Paul states he 'could stand it no longer' (3:5a). As it turned out, the suspense at waiting for Timothy's report and the subsequent relief at receiving it, only confirmed to the apostle that his converts' 'love' and 'longing to see us' was reciprocal (3:6).

A little later in 3:12 Paul actually commends the Thessalonians for the manner in which their love overflows and increases for one another. The apostle desires that such love attain to his own standard ('just as ours does for you' $3: 12$; although see on $4: 9$ below). This might seem an astonishing claim but it is all of a piece with what Paul asks of his readers in imitation of himself elsewhere (cf. 1:6). Thus, an integral part of the Thessalonians' imitation of Paul includes the fact that 'he is [to be] their example of love'. ${ }^{52}$ Paul's remarks concerning his fatherly affection for his Thessalonian children closely parallel the love which fathers in the ancient world were expected to show to their children. One clearly discernible feature of fathers in antiquity which we earlier noted was the fact that they loved their children above and beyond that of their offspring's love for them. One of the reasons for this is that 'parents love their child as soon as they are born' (Aristotle, Eth. Nich. VIII.xii.2), and, since Paul had 'given birth' to the Thessalonians, it is perfectly reasonable that he should cherish his Thessalonian offspring. Paul's love for his 'children' is also understandable against the following comment made by Epictetus when he states that it is impossible for a parent 'not [to] love his own child when it

51 W.A. Meeks, The First Urban Christians: The Social World of the Apostle Paul (New Haven: Yale University Press, 1983), pp. 86-87.

52 Best, Thessalonians, p. 149. It is this affective aspect of Paul's paternity which is missing from Castelli's thesis. 
was small' (Diss. 2.22.12). In response, children were expected to reciprocate such love towards their parents (cf. Aristotle, Eth. Nich. VIII.xii.2f.) and, we have good internal evidence of this in the letter when Timothy reports Paul's converts' affection and 'longing to see' him (3:6).

Note should especially be taken here of the intensity and tenderness of Paul's paternal language in 2:7-8-'we loved you so much', etc. - and the ensuing pericope (2:17-18), which calls to mind similar sentiments echoed by Philo (e.g. Abr. 168; Spec. Leg. 2.240) and Josephus (e.g. Ant. 1.222), which we cited earlier. But perhaps what is most striking in this passage (2:17-20) is the unprecedented outpouring of affection by the apostle Paul as he describes the nature of his separation from his spiritual offspring. It is this which leaves him anxious and, at times, agitated. This requires further attention.

The participle ó $\mu \varepsilon \imath \rho o ́ \mu \varepsilon v o r$, employed in $2: 8$, is not found anywhere else in the New Testament and may reflect the deeper sense of affection Paul felt for the Thessalonians than others of his converts. ${ }^{53}$ This verb is often found on grave inscriptions where it describes the sad yearning of parents for their dead children and is an indication of their affection and attraction. ${ }^{54}$ Now, Paul, in 2:17,

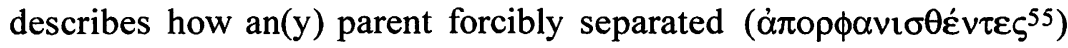
from their offspring would not only yearn for them but long to be reunited again. In the first instance, the apostle reminds the Thessalonians that he is physically ( $\pi \rho \circ \sigma \omega \pi_{\omega} \omega$ ov $\kappa \alpha \rho \delta i \alpha$, 'in face, not in heart', 2:17) separated from them. Clearly, Paul's relationship with the Thessalonians was not a case of, 'Out of sight, out of mind'. By using the above participle, the apostle could very well be likening his separation or loss to that of a death or a 'bereavement'. ${ }^{58}$ In short, the reason for Paul's affection (in part) may be his desire to

53 Wanamaker, Thessalonians, p. 102.

54 Moore, Thessalonians, p. 38. See also G. Milligan ('A Rare New Testament Verb', The Expositor Ninth Series [1924], 226-28]) who cites a sepulchral inscription from Lycaonia where the grieving parents are said to be 'greatly

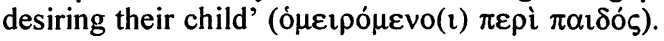

55 This Greek term is much wider then our English understanding of the word 'orphan', and applies also to parents bereft of their offspring. Given that Paul has already referred to himself as a father this is the meaning that is conveyed here. Also, most scholars accept the fact that it was approximately three months after Paul's abrupt departure from Thessalonica that he wrote his first letter to the Thessalonians.

58 L. Morris, The First and Second Epistles to the Thessalonians (NICNT; Grand Rapids: Eerdmans, 1991), p. 87. 
portray 'himself as a bereaved parent'. .9 This should not surprise us since Paul may be reflecting a common expectation of fathers in the ancient world who, upon the death of their child, displayed similar emotive and affective outbursts of grief (cf. Plutarch, Consol. 608D609D; Epictetus, Diss. 3.24.84-94; Quintilian, Inst. 1.3.13ff. all discussed earlier).

The apostle also demonstrated his love for his converts in that he was prepared to work with his hands in order not to be a financial burden to them (2:8-9). By so doing, Paul provides the Thessalonians with what amounts to a graphic and visible expression of his affection for them. This is no small point given the fact that Paul had received some small gifts from other churches (Phil. 4:16) that evidently were unable to meet his financial needs; indeed, the Macedonian churches were generally renowned for their poverty (cf. 2 Cor. 8:1-2). But Paul, rather than make financial demands of his spiritual children, chooses instead to be selfsupporting thereby displaying his kindly feelings and love for them. Thus, this characteristic of Paul's paternity, the characteristic of love, is not regarded by the apostle as an ethereal notion. On the contrary, it expresses itself in concrete acts of service, which is probably why the apostle in turn commends the Thessalonians for 'their labour prompted by love' (1:3).

\section{Conclusion and Implications}

This article has sought to investigate two aspectshierarchy/authority and affective-of Paul's role as 'father' to his Thessalonian 'children'. Situating Paul's role as 'father' against the backdrop of first century Jewish and Graeco-Roman views of paternity, reveals that as far as the first characteristic is concerned the apostle functioned much in the same way as a paterfamilias. He was responsible for the entire socialisation of his offspring. As one who had founded the Thessalonican community, Paul, like the ancients, may even have felt a sense of 'ownership' of the community. However, Paul's relations with his converts, including those at Thessalonica, shows that his preferred method of instructing and dealing with them was to exercise paternal as opposed to apostolic authority.

59 Morris, Thessalonians, p. 87. 
These findings vis-à-vis Paul's patriarchal relations with the Thessalonians-evident in his earliest extant correspondence-are often ignored or overlooked and may have important and profound implications for how we view the structure of these early Christian communities. For example, if it could also be shown that other related familial relations (i.e. siblings) in this letter were hierarchical, then it could suggest that rather than regarding such communities as starting out as non-patriarchal in structure only to be replaced by patriarchal organizations, they were never non-patriarchal at all.

Secondly, we addressed the question of Paul's affective relations with his converts. In spite of the fact that some view Paul's fatherly role as being devoid of all affection, the apostle's love for the Thessalonians is a distinctive feature of this letter and bears similarities with that of fathers in the ancient world. In particular we noted how, for example, physical separation (due to death) in antiquity evoked some of the most affective and emotional outbursts from fathers. This is instructive because not long after Paul established the community at Thessalonica he was forced to make a hasty exit and such a physical separation ('orphaning', 2:17) issued forth one of the most affective and emotional outbursts in the Pauline literature. Paul piles up phrases to demonstrate his sense of 'bereavement' and continued love for his converts.

In conclusion, Paul's role as father is a richly complex one. The apostle's hierarchical relations with the Thessalonians need not, and, in our view does not, exclude the natural affection he also felt and manifested towards his converts. Any proper understanding of Paul's paternal role must account for the dialectic between the power, influence and authority implied in such a role and the benign, affective associations it also implies. 